\title{
Muslim First, Arab Second: A Strategic Politics of Race and Gender
}

\section{Nadine Naber}

University of Michigan

Ann Arbor, Michigan

\section{his article focuses on the deployment of one specific identity category, "Muslim First — Arab Second," emergent among Arab American \\ 1 Muslims in San Francisco, California. ${ }^{1}$ I argue elsewhere that the} racialization of Islam within U.S. state and corporate media discourses, particularly in the aftermath of the Iranian revolution, has provided a socio-historical context that makes the emergence of "Muslim First" as a collective identity possible. ${ }^{2}$ Here I focus on how Muslim student activists have utilized this category as a strategy for articulating Muslim identities in their everyday lives. The narratives behind "Muslim First" are also gendered, deployed by many youths who argue that they provide a broad ideological framework for confronting and reconfiguring family relationships, in particular, their immigrant parents' constructions of masculinity, femininity, and marriage. I also contend that intersections of race and gender are central to the articulation of "Muslim First" identities. When it comes to interracial marriage, for example, "Islam" becomes a vehicle for unsettling parental authority when parents inhibit their daughters from marrying across racial lines.

My argument is that young Arab American Muslims who opt for "Muslim First" as a framework by which to organize their identities are not only constituting themselves as Muslims, but are also constituting new social identities through subject positions set up within discourses and practices specific to the socio-historical contexts in which they live. ${ }^{3}$ Moreover, I will argue that as an identity choice, "Muslim First" is not an exercise in "unconstrained voluntarism" ${ }^{4}$ but is constantly conditioned or regulated by the demands of their immigrant parents, San Francisco's highly charged environment of racial and identity politics, and U.S.-led imperialism in Muslim majority countries. In opening up new possibilities while also regulating the 
possibilities of agency, "Muslim First" enables my research participants to maintain old allegiances with their immigrant communities while simultaneously transforming dominant racialized-gendered regimes of power. Within my research sites, while "Muslim" is first and foremost a religious affiliation and a marker of the relationship between individuals and the divine, it is also a politics of identity, a politics of race, and a politics of gender.

\section{Methodology}

Between January 1999 and September 2000, I conducted field research among second generation Arab Americans in the San Francisco Bay area. ${ }^{5}$ Out of the 35 youths I interviewed whose families were Muslim, fifteen selfidentified as "Muslim First, Arab Second." The voices of these fifteen youths do not reflect debates on identity among all Bay area Muslims. As activists and leaders within their communities, the youths who are the focus of this paper are at the forefront of the formation of new Muslim collectivities. As such, their voices reflect ongoing debates on Muslim identities among activists within Muslim student and community organizations, mosques, and educational institutions.

The contemporary U.S. national context encourages the adoption of "Muslim First" identities. Historically, the U.S. state's racialization of Arab Americans has been located at the intersections of shifting immigration policies vis-à-vis Arab immigrants, changing U.S. policy in the Arab world (such as the confirmed alliance of the U.S. with the Israeli state in 1967), and changing immigration patterns (as in the increase of Muslim immigrants and people displaced by U.S.-led imperialism in the Arab world post-1967). By the late 1980's, as Islamic revival in the Arab world replaced Arab nationalism as the dominant force of resistance to U.S. imperialism and neo-imperialism in the Arab world, state racism against Arab Americans systematically conflated categories and deployed the categories "Arab" and "Muslim" interchangeably. Accordingly, state policies directed at individuals who fit the racialized construction "Arab enemy" before the late 1980's came to be directed at individuals who fit the classification "Arab" and/or "Muslim."

After the attacks against the World Trade Center and the Pentagon of September 11th, 2001, the U.S. has intensified its targeting of persons perceived to be "Arab Muslim," such as "mass arrests, secret and indefinite detentions, prolonged detention of 'material witnesses,' closed hearings and use of secret evidence, government eavesdropping on attorney-client conversations, FBI home and work visits, wiretapping, seizures of property, removals of aliens with technical visa violations, and mandatory special registration." ${ }^{6}$ While the research I conducted took place between 1999 and 2000, I predict that anti-Arab/anti-Muslim racism evident since September 11th 
will further intensify and complicate the process of identity formation among Arab American Muslims.

\section{Everyday Experiences and Identity Formation}

According to Omi and Winant, ${ }^{7}$ preconceived notions of a racialized social structure shape the ways in which individuals use racial codes or meanings to interpret everyday experiences. Similarly, as the U.S. has singled out Arab Americans by enacting particular anti-Arab policies, racialized notions of an "Arab-Middle Eastern-Muslim" enemy become "common sense; a way of comprehending, explaining, and acting in the world." ${ }^{8}$ My research participants' everyday life experiences indicate that preconceived notions about "Arabs," "Middle Easterners," or "Muslims" strongly influenced their identities. The most common racial assumptions that they claimed coded other peoples' interactions with them were that "Arabs/Muslims are terrorists" and that "Arab/Muslim women are the most oppressed women in the world." Tala" explained that in high school, her classmate asked her if "women cover their faces from the bruises they get after their husbands beat them." Maysoun added that "During the Gulf War, I was at a private school and my teacher was from Texas and I had my hand up and he was like, 'put your other hand up.' And he was like, 'that's how all of you need to come, with your hands up.'” Mazen remembered an incident in high school. "It was after the Oklahoma bombing. The junior class president came up to me and said, 'women and children too?' even though the individuals criminally charged for the Oklahoma bombing were neither Arab nor Muslim."

My research participants remembered incidents involving anti-Arab and/or anti-Muslim racism when narrating their own experiences as Arabs and/or Muslims on their college campuses. At a Muslim Student Association (MSA) meeting on a university campus, I observed members developing a plan for dawa (invitation to Islam) that incorporated strategies to help non-Muslim students overcome negative assumptions about Islam. At the same meeting, Rana, who often prayed in public on her college campus, justified the need for such strategies by announcing: "I know that when I pray on campus, they're looking at me with hate."

As state policies, media representations, and everyday experiences situated "Arab Muslims" within the prevailing racial order, Arab Americans who have been consciously grappling with identity politics or student activism in their everyday lives have deployed "strategic essentialism"10 as a mechanism for making demands on institutions and authorities and demanding reform. The category Arab American emerged in the late 1960's when diverse Arab American activists unified under this pan-ethnic label. At the end of the twentieth century, diverse individuals were building a collective identity as 
Muslims to rearticulate their religion and claim their political rights. In turn, representatives of the state have been recognizing Muslims as a political voice. But it is not only national regimes of power that have provided a sociohistorical context for the emergence of "Muslim First." The racial politics of California, and San Francisco in particular, have ignited "Muslim First" identities among local second-generation Arab American youth. According to the census, in August 2000 California became the first state where whites make up less than half of its population. ${ }^{11}$ California's growing racial divide has fueled identity politics among the Bay area's youth populations. As my research participant Mohammed put it, "to be somebody, you have to hang with the Blacks, Asians, Latinos, or Muslims." Like most youth who actively engage in identity politics on their college campuses, my research participants often invoked symbols to mark their identification with a particular group. Rana explained that, "At UC Berkeley, you have to wear bijāb (the veil) to be considered 'cool' in the MSA (Muslim Student Association)."12 But identifying with a Muslim community is not a settled identification. Tala, who feels that the "Muslim First" student group on her college campus is too religious and that the secular Arab group is not religious enough, moved between and among multiple identity groups. While she wore bijāb when she stood in solidarity with her Muslim sisters and brothers at Muslim student rallies and protests, she removed her hijāb when attending secular, "Arab" events.

In the post 1990's political climate, Arab and Muslim community organizations in the U.S. in general and San Francisco in particular have witnessed a shift similar to that taking place in the Arab world. As Islamic revivalism has replaced Arab nationalism as the dominant form of resistance to U.S. neo-imperialism, social movements and community activities organized around the category "Muslim" have increased, while social movements and community activities organized around the category "Arab" have either decreased or remained stagnant. ${ }^{13}$ In addition to the growing visibility of Muslims in the San Francisco Bay area, every Islamic community center has some kind of community program, and every campus Muslim Student Association has become a major site of identity formation and rearticulation. Together, the state's incorporation of Muslims into its prevailing racial order, California's intensifying racial politics and the growing presence of "Muslim" as a communally nurtured identity have set the stage for the performance of "Muslim First" identities among my research participants.

\section{Intergenerational Differences: Masculinity, Femininity and Marriage}

The mobilization of "Muslim First, Arab Second" as an identity label is also ignited by intergenerational differences concerning constructs of masculinity, 
femininity and marriage. My research participants explained that their parents transmitted an "Arab Muslim" identity to them throughout childhood and adolescence. This "Arab Muslim" identity, they stated, was defined in terms of what their parents' generation considered to be abe (shameful) or haram (forbidden/taboo). For example, my research participants agreed that, for Arabs, "it is abe to criticize your family publicly," or it is haram to "follow your desires." However, they explained that neither the things considered abe nor haram were directly defined as being either Arab or Muslim. Being Muslim and being Arab, in my research participants' households, were overlapping identities based on custom and were transmitted through birth and lineage, rather than ones chosen or acquired through rigorous study or individual commitment.

Rania is twenty-eight years old. Her parents are from Beit Hanina, Palestine, which has the reputation of being the most "traditional" village in Palestine among the Arab Americans I met. Rania explained, "I was not raised as a practicing Muslim. I did not study Islam; I did not read the Qur'ān; I did not pray; and my parents did not expect me to wear hijāb." Like Rania, Nidal said that when he was growing up, "the religion was the culture and the culture was the religion. The only thing that made me Muslim was the fundamentals, like there is only one God, Allah, and Mohammed is his last messenger, and the whole idea of heaven and hell and the line of prophets from Adam and Eve on." Otherwise, the distinction between the things that are "Arab" and the things that are "Muslim" were blurred throughout the childhood and adolescent years for most of my research participants.

In their homes, gender and sexuality were the primary terms in which "Arab/Muslim" identity was inscribed. According to my research participants' parents, the components necessary for marriage determine an ideal "Arab Muslim" femininity and masculinity (although the "ideal" varies depending on family, village or country of origin). For example, Palestinians from Beit Hanina were known for believing that ideal daughters "only need to learn to read and write and should not work outside of the home." Hala explained that an ideal Arab Muslim girl should "have a good reputation." A "good reputation" among my female research participants was generally associated with how a woman expresses her sexuality, such as how she dresses, and the extent to which she interacts with men. Hala depicted the "ideal." She said, "She has to come from a good background, know how to cook, and seem like she can be fertile and have lots of kids and be good to her in-laws."

My male research participants also understood "ideal Arab/Muslim masculinity" in terms of marriage. Syrian American Abdullah said that "an Arab/Muslim man has to come from a good family and has to have a good 
financial background," the characteristics that make a male marriageable in Abdullah's household.

Not only did youths recognize the differences between the "normative demands" of "ideal Arab/Muslim femininity" and "ideal Arab/Muslim masculinity" within their households, but they were also conscious of gender hierarchies and double standards embedded within the gender constructs that their parents transmitted to them. Mona explained, "Girls can never go out. Girls have to stay in and guys can go out until three in the morning." Hussein confirmed,

All throughout my lifetime, woman is the cook, woman is the cleaner, taking care of babies and the guy never has to clean. And if he cleans, he's a girl. This is the mentality. This is always how it's been and my sister always throughout my life was always the one cleaning and I was always the one who was enjoying myself and having a good time with the guys and the shai (tea).

In addition to transmitting to their youth normative traits that make a person marriageable, immigrant parents also transmit an ideological consensus about whom the youths were expected to marry. Although there is more pressure on women to practice ethnic and religious endogamy than men, most women and men agreed that, according to their parents, they are expected to marry someone who was both Arab and Muslim. As Jamila put it, "I'm Arabic and I'm Muslim. So my husband has to be both. He has to be Arab and he has to be Muslim."

\section{Crafting a Politics of Gender}

As my research participants' parents regularly referred to particular behaviors as abe or haram and consistently defined and redefined the boundaries of marriage, they participated in the production of norms or regulatory ideals. For my research participants, these regulatory ideals had the effect of differentiating the masculine from the feminine, privileging sons over daughters, and demarcating the boundaries of an imagined "Arab/Muslim" community through a preference for ethno-religious endogamy. Through what they called their parents' production of the regulatory ideals of Arab/Muslim masculinity and femininity, these materialized or stabilized over time to produce constraints in the service of a patriarchal, heterosexual, cultural nationalist and religious imperative.

However, since my research participants "never quite complied with the norms by which their materialization is impelled," ${ }^{14}$ the materialization of "Arab/Muslim" masculinity and femininity was never quite complete. As members of the immigrant parents' generation constructed ideal "Arab/ 
Muslim" masculinity and femininity through the reiteration of norms, their youth discovered gaps and fissures within "ideal Arab/Muslim" masculinity and femininity. Youths strategically relied on these gaps to destabilize norms while calling their hegemonic force into question. For example, youths recognized problems with the ways the categories "Arab" and "Muslim" overlapped in their parents' discourses. They questioned why their parents mobilized the category "Arab/Muslim" as if "Arab" and "Muslim" were one and the same. They asked their friends and their parents, "What are the things about us that are 'Arab' and what are the things that are specifically 'Muslim'?" Using the linguistic tools available to them, the youths developed a shared system for clearly distinguishing between "Arab" and "Muslim," abe and haram, which they saw members of their parents' generation conflating. According to my research participants' reconfiguration, the things that are abe are the things that are forbidden within "Arab culture" and the things that are haram are the things that are forbidden within Islam. In the process of disaggregating "Arab" from "Muslim," my research participants recognized that while "Arab" norms are constrained by an Arab-family-patriarchal-honor-ideal, Islam provides a broader ideological framework from which to refuse, diminish, or displace power and authority. I argue that "Muslim First" identities are constituted through subject positions set up by discourses in my research participants' homes throughout childhood and adolescence. While pre-existing discourses did not determine "Arab/Muslim" identities, they provided the context for their constitution and reformulation. Explaining that their parents relied on the "Arab/Muslim" overlapping category to reinforce family hierarchical relationships, my research participants reconfigured this category as "Muslim First, Arab Second" in order to transform family relationships. "Muslim First, Arab Second" was not a single shift, but the reiteration of new sets of norms.

Central to "Muslim First" youth was the study of Islam and the discourses that shaped their Islamic education in the San Francisco Bay area. Zina was eighteen years old when I conducted my research. She attended courses at an Islamic Institute on various topics, including "marriage," "ethics" and "faith." For Zina, Islam broadened the space for asking questions, seeking explanations, and interpreting the Qurān in the context of her environment. Zina explained,

The culture doesn't provide answers to questions . . . it would just be abe (shameful) if I do this or that. My mom would say, 'Mish kwais lal banat yasawu haka because al nas biyebku alaibum. (It's not good for a girl to do that because the people will talk about her).' I hate those words, 'Abe' (shameful) and 'Nas' (the people). I just want to take them from the dictionary. Like those people at the Arab Cultural Center festivals . . . if the girl is talking to a guy, it's the girl whose 'ilit al âdāb' 
(without manners). The guy, he's just charming. And when I ask, 'why shouldn't she talk to him?' they answer, 'because she's not suppose to.' But then I look at Islam and it takes two. Guys and girls are responsible. The woman has to respect the man and the man has to respect the woman. Also, Islam explains why it's better not to do certain things for guys and girls ... it gives you precautions, and teaches you that rules are for protecting and securing you. Like STD and teen pregnancy, it helps you stay away from it.

Tala was twenty-eight years old and a mother of three when I conducted my research. She self-identified as "Muslim First," unlike her mother and sisters. According to Tala, the more religious she becomes, the more her autonomy within her family increases. She read the Qur'ān, attended Islamic classes, and studied Arabic. She explained that her father was strict, but that it was "more cultural than religious." After becoming more religious, Tala developed a feminist consciousness on women's right to work and be educated. ${ }^{15}$ She explained:

Even though the Din (religion) doesn't say that a girl can't go to school, my father would still say that a woman shouldn't work and a woman shouldn't go to school. But Islamically, she has every right to do so. I think if I had been religious before I got married, I would have said no, its not haram (forbidden) for a woman to go to school or work - if you want your daughter to see a doctor, wouldn't you want her to see a woman doctor over a male doctor? We need women teachers. After the women in my husband's family became much more religious, they are all going to school, all these girls who didn't even finish the eighth grade are now in their late 20's and early 30's and are going to college. They finally broke out of the (Arab) culture. I'm working on my second college degree! And when it comes to working, as a matter of fact, Islamically, what a man makes is for the family and what a woman makes is her choice, whatever she chooses to do with it.

For Zina and Tala, "Muslim First, Arab Second" was strategic in that it provided them with an ideological framework — one their parents could not easily reject - for transforming gender hierarchies. By contesting patriarchal authority in the name of Islam, Tala gained autonomy in the areas of education and employment. This diminished her father's power over her without completely destroying the stability of her family. In fact, Tala, while undermining her father's authority, often gained his respect for her practice of Islam.

While opting for Islam allowed women like Zina and Tala to transform family relationships while maintaining family allegiances, it exacerbated intergenerational conflict and tension for others, especially when parents did not practice Islam. While Iman developed a distinct identity for herself by 
wearing bijāb, rigorously studying Islam and self-identifying as "Muslim First, Arab Second," her father was threatened by his daughter's Islamic consciousness. He equated her participation in Islamic organizations and institutions with participation in a cult but found it difficult to refuse her the rights that she defines as Islamic, particularly among relatives.

Throughout my field sites, "Muslim First" was not only mobilized as a framework for grappling with gender hierarchies between second generation youth and their immigrant parents, it was also mobilized for resisting gender hierarchies in U.S. popular culture, which, according to Lama, "objectify and commodify" women's bodies. Lama remembered,

There was a guy at work who used to go around and grab all the girls and try to touch everything. I told the store manager. The other girls, he would do the same thing to them, but they didn't care, or they didn't care to do anything about it. It was total harassment. And I was like, this is not what I'm about. This is derogatory. I filled out a report and all the other girls didn't support me. But I'm not gonna let some guy do this to me. So that was one of the things that happened to me that made me stronger, that told me, this is your identity. This is who you are, and it all happened when I was around 17 or 18, when I started finding my Muslim identity. I filled out the report and he got fired. Amazing. You can't touch me!

Wearing bijāb was one symbol in particular that provided young women with a newfound autonomy both within their families and outside the home, in public spaces. ${ }^{16}$ As Hiba put it, "It allows you to hold yourself up as a woman with respect (in public spaces). I don't get cat calls." Nour added, "People do not judge me for my body but for my mind," and Ibtisam wrote, in her poem, Muslim Women Unveiled, "my body's not for your eyes to hold, you must speak to my mind, not my feminine mold."

Women were not the only actors who used an Islamic framework for transforming gender inequality. Most of my male research participants regularly argued that Islam displaced gender hierarchies. Twenty-two year old Tawfiq stated:

There is no other system that gives women as much as Islam does ... and not just gives ... but orders a man to do. Some people say a woman can't do this or that in Islam, that she has to stay in the house and can't work. Don't listen to this, none of this. It's the Arabism. That's what destroyed my sister. I wish she understood that that's what destroyed her. She thinks it's Islam. In Arab culture, girls have a hundred and one rules that they have to obey and follow, but the guy can do whatever he wants. It makes me so sad. Guys and girls have to be treated with the same rules within Islam. In Arab culture, girls get depressed because it's so hard on them and guys, they get spoiled and end up wasting their 
lives. I love Islam so much. A Muslim boy and a Muslim girl have the same freedoms and restrictions. You can't give one child, the son, more than the girl. They each have equal rights.

But although youths argued that Islam provides gender equality, their arguments for gender equality were "selective." 17 They tended to challenge certain constructs of masculinity and femininity that their parents transmitted to them while upholding and reinforcing others. ${ }^{18}$ While they critiqued the "Arab/Muslim ideal" among their parents' generation for privileging sons over daughters and denying women equal access to work and education, they consciously upheld the normative demands of marriage and motherhood transmitted to them by their immigrant parents and reinforced by the narratives of Muslim scholars, teachers, and activists. Amina, a leading Muslim activist explained,

Even though many youth discuss gender equality in Islam and use Aisha, the Prophet's wife, who was a scholar, as a role model, a lot of young Muslim women just want to get married right away to have a husband and kids. Even though they say marriage is to fulfill half of their din kind of reason, it's passive and romantic. I've seen a lot of bright girls who dropped out of Ph.D. programs to stay home and have no desire to go back. It's strong, among women, to not desire anything beyond motherhood, even though there are those few strong women who grew up traditionally, were married at 16 or 17, are mothers and housewives, and are also activists. But unfortunately, there aren't many Muslim women activists. I don't see it. The 30 somethings, maybe; but the 20 somethings seem afraid. I'm not excited about them. They're not ambitious. It's rare to find a woman who wants to become a scholar or go for the Ph.D. I understand the desire to be a mother and the demands of childhood, but I don't see or hear the ambition in their voices.

The desire for "passive" and "romantic" forms of marriage and motherhood among the young women to which Amina refers were reinforced by the paradoxical discourses on womanhood among their male counterparts. Tawfiq, who argued that men and women have equal rights in Islam, when he discusses his parents' unfair treatment of his sister, also argued:

If you're a woman, you have certain responsibilities to your family so you can fulfill your religion. That's fine, have your goals and study. If you want to work, work is fine, but Insha Allah, if we ever have a baby, I expect you to put that stuff on the side for that little while ... I'm going to help too, but the mother is everything for the child. Take time for the babies and kids. That's Islamic rule number one, as I see it. And I will help her. I don't expect her to stay at home all day and clean, wash and cook, no! (laugh) and I hope she doesn't expect that. But I do expect the guy to be the breadwinner, the main supporter. I expect the guy to do 
the hard work. He has to be the main guy, Islamically. I want the mother to be with the baby, because the mother affects the baby more than the man. The bond between the mother and the baby is indiscernible, Allah-u Aalum (God knows).

Similarly, Abdul, who regularly said that he supports women's education and career goals and wants to marry someone with whom he can have good conversations, reduced his future wife to an object, calling her "my treasure box" and "my priceless treasure." He explained:

When I find a wife, Insha Allab . . . she's going to be like a treasure box for me ... A priceless treasure which I cannot only make happy by myself, but will also make Allah happy with her. She's like an endless, priceless treasure. I get this message across to all my Muslim brothers, that wife is the most priceless thing you're ever going to have.

Mobilizing "Islam First" as a personal strategy of identity, some male youths clearly used "Islam First" to reinforce patriarchy as well. Rana criticized some of her Muslim brothers who abstained from interacting with her at all on college campuses to protect her reputation for interacting openly with nonMuslim women. Rana said that, "If women interacted with men, especially non-Muslim men in public, they would have a bad reputation." Basim elaborated on this trend, explaining it in terms of "the double standard."

The double standard is when they (Muslim men) won't talk to Muslim girls, but they have no problem talking to American girls. What they'll do is (Muslim) girls would come to Friday prayer, but they won't interact with them at all. But right after that, you'll see all the guys surrounded by, or interacting in a healthy group with non-Muslim girls, like at the university, or at a student club. It's something that happens in the back of their minds, where they'll say, 'our Muslim girls are precious and we want to protect them by not interacting with them in that way.' But then it's okay to go with non-Muslim girls, because it's meaningless anyway.

Just as the "Arab/Muslim" overlap was reinforced through immigrant parents' reiteration of gendered demands or regulatory ideals, "Muslim First" has ideological components, particularly concerning masculinity, femininity and marriage that often regulate or condition the agency of my research participants. But it is the nuances of my research participants' discourses on masculinity, femininity and marriage that support my argument that "Muslim First" is a strategic identity and that it is multiple and shifting, depending on the situation. Both women and men disaggregated the categories "Arab" and "Muslim" and mobilized arguments about gender equality within Islam as a vehicle for developing distinct identities and a sense of autonomy in the face of their parents' authority. Yet women in particular mobilized the category 
"Muslim First" as a framework for transforming gender hierarchies while maintaining family allegiances.

Discourses on gender among my research participants also indicated that women relied on arguments about gender equality within the "Muslim First, Arab Second" framework as a means of self-empowerment in the face of "the American culture's objectification and commodification of women's bodies." In addition, arguments about "Muslim First" among my research participants were often contradictory. Men in particular often argued that "Islam" provides gender equality, but selectively challenged only certain constructions of masculinity and femininity while upholding others.

\section{Designing a Politics of Race}

My research participants relied on arguments about race as they opted for "Muslim First" in the context of the predominantly "Arab" identity transmitted to them by their immigrant parents. One reason why my research participants opted for "Muslim First" was that Islam provided them with a broader ideological framework for developing a "politics of race" and participating in U.S. multiculturalism than did the construction of "Arab" identity transmitted to them by their immigrant parents.

My examination of the ways in which the category "Muslim" was mobilized as a racial project and a politics of race lends itself to a culturally specific analysis about "race." First, the ways in which the racialization of "Islam" have emerged within a particular socio-historical context reinforces the theorization that "race" is socially and historically constructed. Second, as a critique of "racial essentialism," I have shown that race is not fixed or permanent but is unstable and continuously contested, transformed, and rearticulated. Yet "Muslim" identity is not only made possible in the context of social and historical processes. "Muslim" identities are constantly rearticulated by my research participants who are active agents, crafting what it means to be "Muslim."

My research participants tended to argue that "while Arab culture is based on racism, Islam is based on racial equality." Nada, for example, explained that:

Arabs, especially because they own stores in poor black, Asian, or Latino neighborhoods, think that whites are so nice and then they blame certain races for social problems. But in Muslim circles, we learn about the Qurān, and that even though Allah creates you from different tribes and clans to know each other, we're colorblind. The only perfect person is Allah. We're all human, and our skin has nothing to do with the treatment we deserve. A lot of shayks are preaching, when a lot of the people are immigrants, that, in Islam 
we don't see color and we shouldn't treat a black person differently than a white person.

Tawfiq, referring to the mosques during Ramadan, said, "You have people of all origins; Indopaks and Arabs of all origins; you have Sri Lankans, Bosnians, and all these people and they're all coming together because they're all in this local community."

Hussein added that:

At the mosque I attend, it's predominantly Arab and last Ramadan, a black man, so dark, Ma Sha Allah, was leading the prayer every night in front of five hundred people and everyone would go after the prayer and kiss him and hug him, and I just said, 'just if only those people, who talk about Islam and make it so bad, if they were here to see it, they would see, it's nothing about color.' We have Chinese Muslims in our mosque and after the prayer we hug and kiss each other in a loving way, just because we say, "La Ilahi Il Allah," (There is no God but God) that bond means so much. I mean, I've hugged and kissed in a loving way, Filipinos, Blacks, Chinese, Whites, you name it. They're all in the masjid (mosque) together and there's never anything between us.

He referred to the same Aya (verse) Nada referred to, about how . . .

There is no color in Islam. In the mosques, they repeat it a hundred million times to get the point across. "We have created you in tribes or clans so you can get to know one another; but the better ones of you are the ones who fear Allah the most . . ., it doesn't depend on color or anything. And the more I'm reading this aya (verse) the more I'm trying to get this Arab mentality away.

Not only were Nada and Tawfiq critiquing the racism of their parents' generation, they were reconfiguring the 1990's liberal multiculturalism on their own terms. They were retreating from race, supporting universalism, and rejecting race-specific categories within the boundaries of "the Muslim Community." And like the racial neo-liberalism of the 1990's that masked racial conflict behind universalistic reforms, ${ }^{19}$ Nada and Tawfiq overlooked the ways in which racial hierarchies persist among "Muslim First" youths as they grapple with identity formation and articulation. Although a common view that my research participants often associated with "Muslim First" identities was that "There is no Color in Islam," my research participants regularly made references to racial divides within the boundaries of what they refer to as "The Muslim Community."

Mohammed explained that:

Because Arabic is the language of the Qur'ān, and because the Prophet was Arabic, Arabs are seen as the most excellent people. It's ingrained in 
their minds, in the other Muslims' minds. Whenever I'm with a Muslim group, I feel like there are more eyes on me, especially if I'm the only Arab there. It has affected me. Arabs have been given a high position and it always made me feel a little higher, which I hated so much. I feel like I should be respected a little more, Astakhfir Allah Al Azeem (I seek the forgiveness of God), but it's going away now. I'm humbling myself more.

\section{Manal added:}

It becomes better to be Arab in Muslim circles and people look up to you if you're an Arab thinking that you must know Islam more because you speak Arabic and therefore you must be a better Muslim than I am. Arabs are very arrogant about their ethnic background, especially because of the language. They're uptight. It's really appalling. But it's the dream of every Muslim to marry an Arabic speaking person, but Arab men in particular use that a lot in discriminating against the rest of Muslims, especially the African Americans and if left on their own, if not checked by Pakistanis and Indians, they would completely roll over the rest of Muslims.

\section{Bringing it all Home: A Politics of Race and Gender}

Debates over inter-racial marriage linked the ways in which youth mobilize "Muslim First" to transform family and gender hierarchies with the ways in which they mobilized "Muslim First" to transform racial hierarchies. This intersection provides a rich site for examining the concept, "There is no color in Islam," which was central to youths' discourses on interracial marriage. In those discourses, my research participants critiqued the racism of their parents' generation as it intersected with their parents' patriarchal and patrilineal marriage requirements. Since my research participants' parents placed more pressure on their daughters to marry someone who is "Arab" than their sons, interracial marriage as a site of struggle was more important for daughters.

Basem referred to himself as "Muslim first, but Arabic speaking." Like most "Muslim First" youths I worked with, he believed a woman's religion is more important than her "race" or "ethnicity." He said, "I want to love her for her Islam. Marrying a Syrian, or Iraqi, is not important to me.” Manal, an employee at a Muslim organization who deals directly with youth, stated that:

Youth want to marry practicing Muslims like themselves. A lot of the girls want to marry scholars, Muslim scholars, and the guys want to marry a mujahida (freedom fighter), it's amazing. They don't want to marry a regular or ordinary Muslim, they want to marry someone . . . I saw a list of someone who had a list of all the qualifications she was looking for and it was hilarious, it was like the ideal Muslim male, who 
doesn't watch TV, doesn't listen to music, someone she's cloned or something. Its totally unrealistic, but a lot of these girls want to marry these types of individuals.

Arguments about racial equality among "Muslim First" youth were employed by women who used the Qur'ān to convince their parents they could marry across racial lines. Rima told the story:

... (of) these sisters who married the black Muslims . . one of them opened the Qur'ān in her father's face and was like, 'look, it says here, as long as he's a good Muslim.' She put her father on the spot. 'If you're a Muslim, you have to deal with this.' But after they married, the parents sent the younger daughter back home because they were afraid she was going to marry a black Muslim. Let's just say if these Muslims really did read the Qur'ān and practice true Islam, life would be a lot different.

Likewise, Rania, of Jordanian descent, was engaged to an Indonesian Muslim. She said, "My parents were silent because of their guilty conscience." They must have thought, "Allah is going to come one day. This guy is a good man, how could you say no? It's in one of the badiths (sayings of the Prophet)."

According to Jamila,

This generation is really not racist, but they're being made racist by their parents who are trying to get them to marry within their own. Race gets played out within marriage and race issues are debated through Qur'ān, between parents and youth. Kids are really smart, they know Islam. Parents can't say no to interracial marriage. Parents can't get away with it. It's when parents know that the kids don't know Islam, that's when they make up things to sell their point of view. Like, they'll say, 'Islam says so and so.' Or 'No, it doesn't say so.' But usually kids are smart enough to be able to challenge their parents. All they have to do is go to any scholar and ask his point of view.

By mobilizing particular ayahs (verses) from the Qurān, my female research participants developed a politics of race and gender. They challenged the patriarchal and endogamous marriage ideals of Arab families and they sought to unseat the racial prejudices against what many of their immigrant parents refer to as "The Blacks and the Chinese."

\section{Conclusion}

Throughout the period of my field research, second-generation Arab American youths grappled with multiple, competing, and often racist representations of "Arabs," "Middle Easterners," and "Muslims" and with the gendered imperatives of their immigrant parents' generation. They mobilized new categories to claim their identities on their own terms. "Muslim First, Arab 
Second" emerged as one among other vehicles for self-reinvention and public action, particularly among those who participated in Muslim student activism on college campuses. "Muslim First" contests the hegemonic discourse casting everything that is "Muslim" in opposition to everything that is "American." As it disrupts the recurring binary oppositions of "Muslim women's oppression" versus "American women's liberation," and "Jihād" vs. "McWorld,"20 "Muslim First" emerges as a counter discourse through which a politics of race, gender, and identity is imagined and performed.

\section{Endnotes}

1. I developed this paper as a fellow at the Humanities Research Institute, University of California, Irvine, in 2000 in the research cluster, "Islamic Modernities in an Era of Globalization." I am grateful to the research group participants for their contributions.

2. Nadine Naber, "Ambiguous Insiders: An Investigation of Arab Invisibility," Ethnic and Racial Studies 23/1 (2000): 37-61.

3. Michael Foucault, Power Knowledge (New York: Pantheon, 1972).

4. Judith Butler, Bodies that Matter: On the Discursive Limits of "Sex" (New York and London: Routledge, 1993).

5. I conducted intensive interviews with seventy-five Arab American youths between eighteen and thirty years of age of Syrian, Palestinian, Jordanian and Lebanese descent whose parents immigrated to the U.S. in the 1970's. My research participants were Muslim and Christian, male and female; most were either college students or college graduates and most of their parents were small business owners. My research took place within national, cultural, religious and political networks where Arab Americans grapple with identity formation. I attended classes, meetings, conferences, and political and religious gatherings organized by youth, students, and community leaders, and I was regularly invited to dinners and social gatherings in people's homes. Spending extensive time periods at café's and restaurants talking on the phone, and exchanging endless e-mail messages with my research participants was also central to my fieldwork. As an Arab American anthropologist conducting fieldwork "at home," my relationship to my research participants challenged the classical researcher/subject binary. As my fieldwork took place on familiar cultural terrain, where "insider" and "insider" (Weston, 1997) collaboratively deconstructed, contested, and reconfigured the inner-workings of the identities that I set out to "observe," my research developed into an interplay of identity (re)formation between "researcher" and "subject." My gender clearly marked my difference from my male research participants, my physical features and family name rendered me "Arab," but my Christian religious heritage simultaneously distanced me from my Muslim counterparts. This distance was often blurred when we spoke Arabic and when Arab activists, both Muslim and Christian, deployed "strategic essentialism" to resist racist practices which defined all Arabs and Muslims as The Enemy of the West.

6. Cainkar, 2004.

7. Michael Omi and Howard Winant, Racial Formations in the United States (New York and London: Routledge, 1994).

8. Ibid.

9. Throughout this paper, I use pseudonyms to protect the confidentiality of my research participants. 
10. Gayatri Spivak, "Can the Subaltern Speak?" in Marxism and the Interpretation of Culture, ed. Cary Nelson and Lawrence Grossbery (Chicago: University of Illinois Press).

11. Dale Mahridge, The Coming White Minority: California's Eruptions and America's Future (New York: Random House, 2000).

12. See Fadwa El Guindi, Veil: Modesty, Privacy, and Resistance (Berg: Oxford, 1999) for an analysis of the ways in which "veiling in contemporary Arab culture is largely about identity, largely about privacy of space and body."

13. College campuses evidence the increasing visibility of Muslim identities in the U.S. While no Ethnic Studies department in the San Francisco Bay area had ever offered a class on Arab Americans, in fall 2000, UC Berkeley's Ethnic Studies featured a class "Muslim Voices in America." Moreover, since the mid 1990's, Muslim student organizations have become more visible than Arab Student organizations on college campuses.

14. Judith Butler, Bodies that Matter: On the Discursive Limits of "Sex" (New York and London: Routledge, 1993), 9-10.

15. Here, I build upon Lila Abū-Lughod's work (1998) in which she argues that "what is characteristic of the Islamists is that they stigmatize sexual independence and public freedoms as Western but much more gingerly challenge women's rights to work, barely question women's education, and unthinkingly embrace the ideals of bourgeois marriage."

16. Wilhemina Jansen, "Contested Identities: Women and Religion in Algeria and Jordan" in Women and Islamization, ed. Ask and Tjomsland (Berg: Oxford, 1988), 73-102. Here, I build on Jansen, who argues that women who identify as practicing Muslims often gain a sense of autonomy within their homes.

17. Lila Abū-Lughod, "The Marriage of Feminism and Islamism in Egypt: Selective Repudiation as a Dynamic of Postcolonial Cultural Politics," in Remaking Women: Feminism and Modernity in the Middle East, ed. Lila Abū-Lughod (Princeton: Princeton University Press, 1998), 243-270.

18. Ibid. Here, I build upon Lila Abū Lughod's concept, "selective repudiation."

19. Michael Omi and Howard Winant, Racial Formations in the United States (New York and London: Routledge, 1994), 152.

20. Benjamin Barber, Jihäd vs. McWorld (New York: Ballantine Books, 1996). 